\title{
Cultural (Mis)Appropriation, Ideological Essentialism and Language: Analysis of Stereotyping in Hollywood Movie
}

\author{
Inayat Ullah $^{1} \&$ Kulsoom Shahzor ${ }^{2}$ \\ ${ }^{1}$ Assistant Professor at the Department of Humanities (English), Air University, Islamabad, Pakistan \\ ${ }^{2}$ Department of Humanities (English), Faculty of Social Sciences, Air University, Islamabad, Pakistan \\ Correspondence: Inayat Ullah, Department of Humanities (English), Air University, Islamabad, Pakistan. \\ E-mail: inayat_ktk@yahoo.com
}

Received: July 25, 2017 Accepted: August 17, 2017 Online Published: September 25, 2017

doi:10.5539/ijel.v7n6p171 URL: http://doi.org/10.5539/ijel.v7n6p171

\begin{abstract}
This study analyzes the monolithic-cum-essentialist portrayal of the non-Euro-American world in Hollywood movies, bringing forth the fact that the project of Othering is still at play but in different manifestations. This qualitative research endeavors to apply the concept of Orientalism to carry out a postcolonial analysis of the movie American Sniper. As Edward Said, decades ago, proposed a way to understand the notions of the West regarding East in his famous work Orientalism, the study helps to understand the embedded ideologies which are promoted through movies, and the way these discourses are used to shape the Western worldview about the East. The study highlights the fact that Hollywood, famous for entertainment and advanced motion pictures, is also being used for shaping the narrative of the superiority of the West. As Islam and Arabs have always remained in the limelight of the Hollywood movies, this special association of the entertainment media with the Islamic Orient is not just for the purpose of amusement but also to (un)consciously build unbefitting images of the East and portray it as a monolith of an inferior status for the common viewer in the West.
\end{abstract}

Keywords: Orientalism, Discourse, Hollywood, American Sniper, Othering, Western Agenda

\section{Introduction}

Portraying life in its varying manifestations, cultural productions cover issues ranging from everyday life to the heroics of protagonists in war narratives. Recording all facets of existence, it grows, adding memories to its vastness. Like other depictions of these cultural productions which have grown since the olden times, war narratives have also remained an important essential of literature. Sartre (1960) rightly said "When the rich wage war, it is the poor who die" (p. 2). Of great importance for both rich and poor for complete different reasons, war is the most feared of all human aspects, at all times glorifying the victorious and ignoring the fact that it is human's worst enemy. Zusak (2003) states about the horrors of war and the triumph of death, that "I've seen so many young men over the years who think they're running at other young men. They are not. They are running at me.” (p. 3) This insatiable urge for grandeur at the cost of human lives led to the desire to seize more and more lands in foreign countries, necessitating the need for the powerful nations to discover foreign countries and colonize them. The history of colonialism is filled with details of the powerful European nations colonizing the poor ones, subjugating them and exploiting their resources to send the riches back home.

Commenting on the latest manifestations of neocolonialism, Ullah \& Aib (2017) assert that "A hidden agenda behind colonialism was the occupation of the lands to transform them into a commercial venture for the Western colonizing nations" (p. 8), the United States of America, being a superpower always stretched its arms, and gulf region has suffered the most because of this passionate yearning of the States. As Twain (1995) sarcastically said that "God created war so that Americans would learn geography" (p. 3).

The conflict that started with the invasion of Iraq in 2003 and ended in 2011 converted the country into rubbles and a headless state, having no fate and an uncertain future. For those Americans, celebrating their nation's stance, it was difficult to realize the price an Iraqi had to pay for this so called just war. Documented Iraqi civilian deaths from invasion of the US forces ranged between 174, 174 to 194, 569 (Iraq Body Count). The total number of American veterans, who died was almost 4,486 (Huffington Post). The aforementioned destruction found coverage not only in new broadcasts but also literary productions, where the whole series of events was presented wrapped 
in discourse emanating from varying ideological standpoints. Movies, apart from other literary forms, are also an important means of imparting ideology to audience. It transfers the message safe and sound, motivating the masses in either direction. When it comes to war movies, it is mostly with a running agenda as, for a layman, it is not just a motivation to, and an appreciation of, the nation's warrior but in fact an ideology transfer, which somehow stays with individuals and is stored in their memories.

Based on the war in Iraq, American Sniper is a movie which took the cinema by storm and got 7.3 rating on IMDB, depicting American course of military action in Iraq and the state of mind of a US soldier, carrying the license to kill. Based on a true memoir of the US veteran, Chris Kyle, a Texan born, who was deployed in Iraq in 2003 and was known as the most lethal sniper of all times, with more than 200 killings to his credit. Kyle operated with the ideology of taming the so called savages, and his task was deadly but the question is who transferred this schema into his mind and the orientalist deigns at his back. He was just a play card along with his fellow men, blindly obeying orders coming from the power structures.

Past 9/11, descriptions of the Muslim "Other" have been at hype in the Western world. Entering such frame of mind is mainly due to the negative stereotyping that manifests itself in various forms, including xenophobia and islamophobia, the two phenomena which witnessed new heights in the post 9/11 global north (Awan, 2010; 2013). Edward Said's Orientalism that came out many decades ago still provides a lens to view the west and to examine how these descriptions and movies function in spreading the discourses against Muslims and war on terror. Said's work helps us study the confusing concept of superiority and inferiority on part of east and west. This article views the ideology prevailing in Hollywood and the Orientalism that is still alive in their media in the light of the movie American Sniper.

\section{Research Objectives}

- To identify the grounds of bias as manifested in the Hollywood movies

- To locate the presence of Orientalism in US mindsets in the present world

- To examine the stereotyping, Othering and the notion of west and east in the backdrop of the movie American Sniper

\section{Research Questions}

- How do Hollywood movies portray oriental designs, as portrayed in the movie American Sniper?

- Does Orientalism prevail in our society today and authenticates itself through the film/media discourses?

\section{Significance of the Study}

For a layman, movies are part of entertainment after busy schedules as these serve as mind relaxers; however, the study shows that if a movie is based on national issues, it serves as an ideologically driven patriotic feed to the masses. This study is significant in showing how the concept that a layman lacks is the way the slowly injected ideologies are being promoted through such productions. In case of American Sniper, on the surface level, it does show a man and his sacrifices, a legend who saved many and killed many in honor of his nation; but on the deeper level, it unconsciously injects hatred, disgust and monolithic views about the east. Though a common American has never been to Iraq but this movie is sufficient to build his view regarding the people and their state. This all comes in the domain of Orientalism, which is shown as justified in the movie. In short the major significance of this research is locating Orientalism in Hollywood movies, keeping in consideration American Sniper.

\section{Delimitation of the Study}

Edward Said's book on Orientalism discusses many aspects of the concept of the West regarding East and gives a way to see the mindset of Colonizers or White masters. It also gives us a way to get out of that preconceived notion regarding east. This research paper is limited to study of Orientalism specifically with reference to American Sniper and the concept of West and East, Othering and Stereotyping.

\section{Methodology and Theoretical Framework}

This paper is qualitative in nature with primary source of investigation as the movie and secondary sources include the memoir of Chris Kyle and other related works and articles. The theoretical framework comprises of postcolonial studies, with focus on Edward Said's Orientalism, delimited to three broad categories. The technique used for investigation is textual analysis.

\section{Analysis and Discussion}

Huiskamp, Dorzweiler, \& Lovely (2016) investigate the popular use of media in shaping the mindsets of 
individuals and how ideologies are formed silently by the power structures. They studied the fact how in 2003, Red Dawn, the mission led against Iraq and Saddam Hussein, was named after the movie against Soviet invasion. These movies filmed purposely during these war times encouraged insurgency in Iraq. These movies help people and individuals to understand the political problems and evils. Pomarède (2016) carves down the fact that "war on terror" is very popular phrase among US veterans. The soldiers fighting on the front lines give a deep image of the war to people staying back. The legendary American sniper, posted in Iraq, Chris Kyle, was known as "the most lethal sniper in the US military history". He further writes that studying about his accomplishments brought forward two main aspects; American sniper is enfolded in apolitical setting, saving interests of the few and secondly war appears at both ends, struggle for life makes you crude enough to kill and survive and human emotions that are witnessed even in the eyes of enemies. Spaeth (2009) one day while working out in gym, watching television at the same time, she listened to the reporter throwing questions regarding the condition of American soldiers in Iraq and that whatever America was doing in Iraq and Afghanistan was justified or not. A young soldier doing cardio next to her threw the same question at her to which she replied that yes whatever states was doing was just and ethical. To this the young soldier replied that he had mixed feelings about this war, States was not doing all right. He left the gym and she was left in trance as a reply like that was unexpected from the veterans of the states. The point is everyone is free in opinion. Sitting in home and commenting on war is trouble-free but fighting in the battlefield with many relations ahead of you, is intricate.

This book is covering many facets at a time from academic arena to literature and from geopolitical scenarios to everyday life of soldiers. She has given true narratives of veterans of the States and writes that "Luckily, many soldiers haven't kept that hurt locker closed indefinitely, and open it to write or otherwise tell their stories.... These stories are thrilling, painful, lovely, horrific, and intimate. It benefits all of us if, when the locker opens and the voices begin, we listen" Peebles (2011). "In this book, I examine a selection of contemporary war stories from the Persian Gulf War and the Iraq War... I show how these newest stories have a new twist, even as they address familiar, even ancient subjects" Peebles (2011).

Franklin (2017) stated that Politics and film may appear as different areas of study but the concept of film politics is gaining new hype at this course of century. Movies like American sniper, 12 years a slave (2013) and other seasons despite initiating counter discourse and controversy have given insights into government's popular stance, political punishments, terrorism and overall policy making. The point worth mentioning is that film media is now on the voyage of exploring all historical upheavals.

Tanguay (2015) said that a number of films coming in initials of 2000 criticized the "good war" stance of G. W. Bush. Movies such as American Sniper and Zero Dark Thirty (2012), despite having critical acclaim still remained controversial because the audience was still puzzled between the good and bad war and the expedition laid on as "war of terror". Maass (2015) the "impeccably crafted" movie that took the American nation by storm, failed to tell both sides of the story. We kept on decorating Chris Kyle and forgot to locate the impact it generated among public. "A war movie that is true of one American's experience can be utterly false to the experience of millions of Iraqis and to the historical record". Hollywood till date fails to portray the real depictions of war. Maass (2015) forced on the notion that "We got Iraq wrong in the real world. It would be nice to get it right at the multiplex".

Reppenhagen (2015) says that when a soldier speaks for a soldier it carries weight and strength. Reppenhagen gave his reservations about American Sniper and told that he never saw Iraqis as savages, though when you are deployed at another part of the world, away from home and family, you make your mind that it's a matter of high risk security but that does not allow us to label and measure all of them as one.

Richards (2017) inquired that Media has always remained as an influential character saving the interests of few and depicting negative on behalf of others. Western Media has been in past few decades doing all this evidently against Muslims, generating Islamophobia and reviving the stance of Said's Orientalism. Khalid (2011) focused that gender has always given prominent importance in orientalist discourses. The discourses constructed after the war on terror have given new meanings and revived the concept of "other" validate armed association in Afghanistan and Iraq. Wall (2011) argued that the soldier has to justify his inhumane treatment towards the other part of world and to talk rationally about his mother state American soldiers keeping in mind this notion make an image of themselves and the "other" to legitimatize this war. Al-Ghadeer (2013) said that American nation which claims to be the flag bearer of civilization and taming the savages has himself broken the truce of humanity, Iraq and the unjust war, the extreme stereotyping and the cannibalism on the Abu Ghraib prison, is enough of the evidence to prove the double standards adopted by this state. 
Shaheen (2013) in his research says that it's been long that we have been witnessing anti Muslim and Arabs stances worldwide. They are projected as "Bedouin bandits, sinister sheikhs, buffoons, and gun wielding terrorists." Even the animations have projected the stereotyping in the animations considering the case of Aladdin (1992) we see this song "from a faraway place, where the caravan camels roam, where they cut off your ear if they don't like your face. It's barbaric, but hey, it's home."

Mesic discusses about the terms media has associated with Islam and Muslims. He uses three terms regarding Muslims and Islam as "fundamentalism", "extremism" and "radicalism". On Iraq war, Tony Blair quoted that "Military action by the US and UK followed and a certain amount of infrastructure for Iraq's WMD and missile capability was destroyed, setting the Iraqi programme back, but not ending it".

Chomsky (2004) says that "The number of people killed by the sanctions in Iraq is greater than the total number of people killed by all weapons of mass destruction in all of history." Hollywood is a worldwide hub of fame. Covering all genres of life, it paces ahead with an ideology. The movie American Sniper, which on surface level rotated around one man's show and sacrifice, had greater intentions and agendas at grass root level. Having in focus the Iraq war, this movie only glorified a US marine/seal, forgetting about the whole Iraqi nation and their countless sacrifices, courage and patience in seeing their nation turning into rubbles. Why US attacked Iraq is a big question? The answer lies in four segments, as shown in the movie, the falling twin towers and then suddenly the location of Al Qaeda in Iraq was enough to mobilize the forces. Other reasons which gave heat to this high mark attack included, WMD in Iraq, their transfer to Al Qaeda which was a threat to US nation and finally America wanted to bring human laws and principles in Iraq, he wanted democracy. Now who gave America this authority is another big question. According to Said (1978), America has dominated the orient since Second World War. The Orient refers to the East. US always had an inclination towards Muslim orient, as oil spills in these nations. Said says "Islamic Orient has had to be the center of attention" Said (1978).Unfortunately the years long fight ended with increasing death tolls only as WMD was never located and USA failed to keep all his promises.

Coming to the movie, Kyle being a passionate individual, ready to save the greatest nation of earth, leaves for Iraq on a merciless mission. A place of romance, striking beings and haunting recollections for Said is grounded and the scenes depicting the terrified Iraq are obvious as we witness ruthless killing of humanity just for greater interests of US. Debris all along the streets of Iraq, devastated buildings and infrastructure, "Looted shops, burnt awnings" (Eastwood, 2014), life in Iraq is put at halt. On one occasion it is witnessed that a dog is eating human flesh, there on the road side, as the tamers have started the mission of making humans out of Iraqis. Said says that "We allow justly that the Holocaust has permanently altered the consciousness of our time: Why do we not accord the same epistemological mutation in what imperialism has done, and what Orientalism continues to do?" Said (1978). Because of such movies, Hollywood only glorifies the orientalist, not concerning about the consequences these discourses generate. This analysis is now portioned in 3 concepts of Said and they will be supplemented by the instances from the movie and from Said's work of Orientalism.

\section{Concept of West and East}

Said (1973) says that "Orientalism can be discussed and analyzed as the corporate institution for dealing with the Orient — dealing with it by making statements about it, authorizing views of it, describing it, by teaching it, settling it, ruling over it: in short, Orientalism as a Western style for dominating, restructuring, and having authority over the Orient".

Edward said says that for the West, East has always remained a career. In the movie we see Chris Kyle as a patriotic individual who is not getting into the details of reality behind the events, jumps into Seals and heads to Iraq. "Cause it's the greatest country on earth and I believe it's worth protecting." (Eastwood, 2014).Who generated these binaries of greatest and insignificant, who labeled America the greatest of all? Who preached this ideology to the people?

For Said "He comes up against the Orient as a European or American first, as an individual second... It meant and means being aware, however dimly, that one belongs to a part of the earth with definite interests in the Orient and more important, that one belongs to Part of the earth with a definite history of involvement in the Orient almost since the time of Homer" (1978).

For US, entering into another state without legalizing it is nothing but a power structure that goes like this. For them for the glory of west it is needed. The glorified and educated west needs to transfer few traits in the east as well. As shown in the movie, they are on a kind of civilizing mission, as one of the colonel instructs the marines that they have to put the fear of God in those "Savages" (Eastwood, 2014). As West is on a mission to East, so for those maintaining human ethics is also important as their actions are noted every moment in the eyes of God. For them they are killing in a righteous manner and can stand on the Day of Judgment proudly that they lifted the 
burden of East on their shoulders as well, by protecting what was not their job. "We're protecting more than this dirt" (Eastwood, 2014).

In the beginning of the movie, young Chris gets a lesson on survival after he saves his brother from getting beaten up by school boys. He remembers the same concept after coming to Iraq. His father instructed him that there are some people for whom evil doesn't exist and they cannot protect themselves in the times of danger as they are the "sheep", and then there are those who are violent and attack the weak "the wolves" and finally we have few individuals who are gifted with aggressive powers to stand against the wolves and protect the flock- "the sheepdog". On the surface level, this statement is pure and humane but what lies beneath the skin is what makes west and east, the sheep refers to American nation, the wolves are the Islamic orient while sheepdog refers to the veterans who are protecting their nation against those "savages". During the mission one of their fellows dies and in response the so-called civilizers make a firm statement of "Eye for eye, tooth for tooth" (Eastwood, 2014). At another occasion, being on a strong and superior side, Chris Kyle, in his memoir writes, that killing people randomly at first sounded absurd but later I came to know that it was no different from other tasks.

\section{Stereotyping}

Edgar and Sedgwick identify the notion that "a stereotype is an oversimplified and usually value laden view of the attitudes, behavior and expectations of a group or individual. Such views, which may be deeply embedded in sexist, racist or otherwise prejudiced cultures, are typically highly resistant to change." (p. 380). The Hollywood movie has played a negative role in stereotyping about the East, depicting in movies and other programs, the savagery has always been given to this part and somehow these concepts have been embedded in the people of West. As we see in the movie, Iraqis though protecting their land from the foreign intruders have been labeled as "Savages" on numerous occasions. They have been abused when they try to counter the US marines and killed ruthlessly. The stereotypes that have been created by media are enough for a marine who has never left his land and landed on a totally new world.

Said (2003) asserts that "Arabs, for example, are thought of as camel-riding, terroristic, hook-nosed, venal lechers whose undeserved wealth is an affront to real civilization. Always there lurks the assumption that although the Western consumer belongs to a numerical minority, he is entitled either to own or to expend (or both) the majority of the world resources. Why? Because he, unlike the Oriental, is a true human being." Now the point of understanding is that western media and their hierarchy created these concepts. For them an Arab is all in all described above, not conforming to this is a threat to the West. On the one side, stereotypes are created so strongly for Arabs while, on other side, we only witness "true human beings". Plenty of instances can be quoted from the movie regarding this monolithic approach. Chris Kyle all along his made a journey in Iraq but never uses a humane vocabulary for Iraqis rather his only stance regarding them is "savages". Other expressions that he along with his fellows use, include: “*** hajjis", "bad guys", "uglies" "Saddam's bitches" and humans full of hate etc. For Chris, killing those savages is such a pious task that God showers his help all the way along. His heroism regarding the Iraqis is described in the movie when he kills them in a row and after that receives huge appreciation from his fellows: "laces bad guys. Pure brutality. They fall at his feet." (Eastwood, 2014).

The labeling is so obvious that Chris Kyle is throughout the movie called as "the legend" and his fellows are called true US patriots while the others are representing just plain wickedness. In his memoir, Chris Kyle wrote many a times that all they were fighting back in Iraq was evil and savagery. When Kyle kills Mustafa (the Iraqi sniper, who has become a nightmare for US marines), the satisfaction of rooting out the evil is evident on his face. Kyle wrote in his memoir that all I could wish was to kill more of these people, it was not about one to one hatred but the notion that the world was a much more peaceful place to live in. Keeping in mind the fact that the situation was opposite to this, the Orient is always portrayed negatively as if no good has to come out of it. The language usage is full of labels that is ruthless and filled with hatred against enemy. Said (2003) says that "Even the language of the war is dehumanizing in the extreme: "We'll go in there take out Saddam, destroy his army with clean surgical strikes, and everyone will think it's great", said a congresswoman on national television." (p. 2)

American Sniper as a movie that has generated so many stereotypes about Iraq by the people who have never been there, and for them, this Orient was no less than a savage and evil centered land. This is how the Hollywood movies propagate Orientalism among masses.

\section{Concept of Othering}

The binary oppositions created in olden times in theories and other works of both fact and fiction, unfortunately still prevail in the society. The distinction is not just between the haves and haves not but rather it goes on a bigger scale, covering whole nations. Said (1978) gave his concept of Othering, and regrettably the nations of the world 
are still stuck in this concept till date. In the movie, so many instances of Othering and marginalization are witnessed. West and East are two oppositions and none of the elements of human ethics are common as per the US soldiers in the movie.

The question arises who gives these US veterans including Kyle the right to mercilessly kill the Iraqis. It is no act of courage or for that matter valor to kill a human just because your ideology and ways to life differ and put him on a dreadful fate. Throughout the movie, the Whites dehumanize the Browns and demarcate the world into wolves and sheepdogs — good and evil.

Said stresses on the aspect that "The relationship between Occident and Orient is a relationship of power, of domination, of varying degrees of a complex hegemony..." (1978), and as shown in the movie, the fighters are bare-footed but equipped with hand grenades, trying to intrude into the lines of the skilled seals who, on the other hand, are equipped top to toe and are having the ill of kill in their heads. At another occasion "This is our home. I won't give it to them" (Eastwood, 2014). Forgetting the point that they attacked Iraq, which did not break the sanctity of their nation, it was a false pretense on which this whole war was formulated. The concept of us and them, ours and theirs is very obvious. At another occasion, the instructor warns them that these Iraqis are very stubborn beings and even if you beat them, they do not stop, they come again for more as if it is some pleasure seeking exercise.

The concept of us (west/superior) versus them (east/inferior) has been discussed at length in his book as Said rightfully strikes at the western ideals of the superior Occident and claims that "Were Iraq to have been the world's largest exporter of bananas or oranges, surely there would have been no war, no hysteria over mysteriously vanished weapons of mass destruction, no transporting of an enormous army, navy, and air force 7,000 miles away to destroy a country scarcely known even to the educated American, all in the name of freedom. Without a well-organized sense that these people over there were not like "us" and didn't appreciate "our" values- the very core of traditional Orientalist dogma." (p. 1, 2003)

This point raised by Said is enough to understand the lobby behind this large scale destruction in Iraq, and as evident from the movie, they were the world's largest oil producers but now the whole nation has been turned to rubbles.

\section{Conclusion}

American Sniper may be just a movie about one man and his legendary acts for his nation but it does have many other interpretations as discussed in the analysis. Hollywood, being a media hub that is not only famous for technologically advanced depictions but is also critiqued for its essentialist oriental depictions, finds itself, quite often, grappling with the latter blind spot of its operations. Though Said (1992) wrote about Orientalism a number of years ago, it still functions in varying manifestations in the global power structures; irrespective of matter how much lip service is paid to the discourses of equality between the different nations of the world. It goes without saying that the hegemony of the West prevails over the East, no matter how much the East flourishes, it is always portrayed as an undeserved wealth which should be taken by the Occident under once pretext or another. The concept of West and East, stereotyping and Othering explained in the analysis prevails in the two divided spheres of this world. The study shows that the there is a need to accept the East as it is, rather than necessitating, rationalizing and enforcing discourses in varying forms to look down upon it and stereotyping as inferior, wild, uncivilized and open for interpretation under the Western canon.

\section{References}

Al-Ghadeer, M. (2013). Cannibalizing Iraq: Topos of a New Orientalism. Debating Orientalism, 117-133. https://doi.org/10.1057/9781137341112_7

Awan, S. M. (2010). Global Terror and the Rise of Xenophobia/Islamophobia: An Analysis of American Cultural Productions Since September 11. Islamic Studies, 49(4), 521-537.

Awan, S. M. (2013). Unwilled Choices: The Exilic Perspectives on Home and Location in the Works of Zulfikar Ghose and Mohsin Hamid. Pakistaniaat, 5(2). Retrieved from http://pakistaniaat.org/index.php/pak/article/view/225/232

Chomsky, N. (2004). On Terrorism. Jumps Arts Journal.

D'Amato, P. (2005). Is the Iraq war just about the oil? Retrieved from http://socialistworker.org/2005-2/563/563_09_OilandWar.shtml

Eastwood, C. (2014). American Sniper [Video file].

Franklin, D. P. (2017). Politics and film: the political culture of television and movies. Lanham: Rowman \& 
Littlefield.

Full text: Tony Blair's speech. (2003). Retrieved from https://www.theguardian.com/politics/2003/mar/18/foreignpolicy.iraq1

Gerard Huiskamp, N. D. (n. d.). "Watching War Movies in Baghdad: Popular Culture and the Construction of Military Policy in the Iraq War".

Hall, J., Kyle, C., McEwen, S., \& DeFelice, J. (2015). American sniper:. Burbank, CA: Warner Bros. Pictures.

HuffPost-Breaking News, U.S. and World News. (n. d.). Retrieved from http://www.huffingtonpost.com/

Khalid, M. (2011). Gender, Orientalism and representations of the "Other" in the War on Terror. Global Change, Peace \& Security, 23(1), 15-29. https://doi.org/10.1080/14781158.2011.540092

Maass, P. (2015). How Clint Eastwood Ignores History in "American Sniper". Retrieved from https://theintercept.com/2015/01/08/clint-eastwood-ignores-history-american-sniper/

Mirza MEŠI, Ć. (2013). The Perception of Islam and Muslims in the Media and the Responsibility of European Muslims Towards the Media.

Musker, J., Clements, R., Musker, J., Clements, R., Musker, J., Clements, R., ... Larkin, L. (1992). Aladdin [Video file]. (n. d.). Retrieved from https://www.iraqbodycount.org/

Peebles, S. (2011). Welcome to the Suck: Narrating the American Soldier's Experience in Iraq.

Pomarède, J. (2016). Normalizing violence through front-line stories: the case of American Sniper.

Reppenhagen, G. (2015). I was an American sniper, and Chris Kyle's war was not my war. Retrieved from http://www.salon.com/2015/02/01/i_was_an_american_sniper_and_chris_kyle $\% \mathrm{e} 2 \% 80 \% 99$ s_war_was_not _my_war/

Richards, B. (2017). Evidence and ideology: moderating the critique of media Islamophobia.

Said, E. (1980). Islam through Western Eyes. Nation, 230(16), 488-492.

Sartre, J., Black, K., Sartre, J., \& Sartre, J. (1960). The Devil \& the Good Lord, and two other plays. New York: Vintage Books.

Shaheen, J. (2013). Arab and Muslim stereotypes can be changed by the entertainment industry.

Spaeth, P. A. (2009). Not "Just a Theory".

Tanguay, L. (2015). The "good war" on terror: rewriting empire from George W. Bush to American Sniper. Critical Studies on Security, 3(3), 297-302. https://doi.org/10.1080/21624887.2015.1123955

Twain, M. (2008). The innocents abroad. Charleston, SC: Bibliobazaar.

Ullah, I., \& Aib, I. (2017). Discursive Strategies and Politics of (Neo-)colonialism: A Textual Analysis of Saadat Hassan Manto's Letters to Uncle Sam. International Journal of English Linguistics, 5(7), 8-18. https://doi.org/10.5539/ijel.v7n5p8

Wall, T. (2011). Philanthropic Soldiers, Practical Orientalism, and the Occupation of Iraq. Identities, 18(5), 481-501. https://doi.org/10.1080/1070289X.2011.671710

Zusak, M., \& White, T. (2016). The book thief. New York: Alfred A. Knopf.

\section{Copyrights}

Copyright for this article is retained by the author(s), with first publication rights granted to the journal.

This is an open-access article distributed under the terms and conditions of the Creative Commons Attribution license (http://creativecommons.org/licenses/by/4.0/). 